\title{
Filling the Gaps: Arbuscular Mycorrhizal Fungi Biodiversity in the Tropical Ecosystems
}

\author{
Geofrey E Soka* \\ Department of Wildlife Management, Sokoine University of Agriculture, Tanzania
}

*Corresponding author: Geofrey E Soka, Department of Wildlife Management, Sokoine University of Agriculture, P.0. Box 3073, Tanzania, East Africa

Submission: 酑 September 09, 2017; Published: 眥 February 23, 2018

\section{Introduction}

For a long time it was inequitably assumed that Arbuscular Mycorrhizal Fungi (AMF) was poorly represented in the tropics, so this area remained rather unexplored. However, recent research suggests that the tropics contain a treasure of unknown species of AMF. AMF are more widely distributed and can associate with a wide range of plant species [1-3]. Arbuscular Mycorrhizal (AM) symbioses can be formed with as many plant species as 250,000 [3]. To date, only 150-200 species of AM fungi have so far been distinguished on the basis of morphology [4]. However, DNA-based studies suggest that the true diversity of these symbionts may be much higher [5].

AMF are important microbial symbioses for plants in nutrients poor soils [6-8], and are significant in the maintenance of soil health and fertility, plant community development, nutrient uptake and above the ground productivity [1,2,9]. Plants exchange carbon (C) for fungal phosphorus (P) and nitrogen (N) [10-12]. AM fungi release signals molecules, which trigger a series of symbiotic plant genes; this activity prepares the intracellular root environment for colonization and arbuscule formation inside the root cortex [13,14].

Mycorrhizal fungi are known to influence plant diversity patterns in a variety of ecosystems globally [15]. Studies have been undertaken on the distribution and diversity of AMF species in relation to individual plant species and plant communities in farming systems in temperate regions [16-18]; and recently, there is emerging interest in the role of mycorrhizae in ecosystem processes [19-21]. Although AMF have been extensively studied in temperate regions, the effects of land management and land cover changes on their abundance and their contributions to plant productivity in nutrient-poor tropical soils is still unclear [22]. It is well recognized that humans keep on changing the global environments at an unprecedented rate. These changes are known to have an impact on global climate and biota; however, the implications of these changes to communities and ecosystems are not known [23]. Understanding of the mycorrhizal responses to anthropogenic environmental changes can therefore help to predict the trajectories of future communities and ecosystems in a changing world [24-25]. Soil has been reported to be a complex system wherein chemical, physical and biochemical factors are held in dynamic equilibrium [26]. Studies of AM hyphal abundance provide information on the biochemical processes occurring in soil $[8,22]$. There is growing evidence that soil biological parameters may be potential and sensitive indicators of soil fertility [27] and management induced changes in soil quality [28].

It is crucial to assess the effects of conversion of natural vegetation for agriculture to determine the effects of land use and cover transitions in AMF abundance in nutrient-poor tropical soils. Studies carried out in agricultural systems both in the tropical and temperate regions have suggested that AMF abundance may decline as a result of tillage [17,22]. Whilst reports of AM hyphal abundance in agricultural soils are becoming increasingly common [29], our knowledge of them in natural ecosystems remains scant. Knowledge about mycelial abundance is important in comprehending the potential roles of fungi in nutrient cycling, and plant symbionts. At present, little is known about the control of abundance and diversity of AMF in nutrient-poor tropical soils and; given the increasing importance attached to mycorrhizal fungal diversity for maintenance of ecosystem functioning, a better understanding of the causes of AMF diversity and its loss is deemed necessary.

\section{The Way Forward}

Since little is known about host specificity among AMF in tropical savanna soils, it is important to understand whether different plant species associate with unique communities of AMF, and how increasing plant diversity affects the composition of AMF communities. Therefore, further research into plant host effects and AMF community diversity needs to be disentangled experimentally. Understanding how plant hosts affect AMF communities can also inform restoration and conservation projects, allowing researchers to better understand the contribution of different mycorrhizal communities in plant productivity [30].

Fire can affect AM fungi by changing the soil conditions and by directly altering AM proliferation. No study has been conducted to 
examine the effects of fire on AMF abundance in tropical savanna soils. Therefore, the assessment of the effect of fire on AMF abundance is clearly needed. Future studies should endeavour to use molecular methods to determine AMF species diversity in tropical savanna. Use of fungal operational taxonomic units (OTU) would help to detect the diversity of Glomeromycota in tropical savanna soils. The assessment of AMF using molecular-based approach is necessary to affirm AMF diversity in tropical ecosystems. Albeit, environmental sequencing in the tropics is emerging, still solid taxonomic data essential to interpret the genomic datasets resulting from these studies are lacking. Therefore, there is a to bridge the gap between data generated by environmental ecologists and the knowledge gathered by taxonomists, in order to make a full assessment of biodiversity possible by linking above ground diversity to below ground diversity.

\section{References}

1. Smith SE, Read DJ (1997) Mycorrhizal symbiosis. (2 ${ }^{\text {nd }}$ edn), Academic Press, New York, USA.

2. Brundrett M (2004) Diversity and classification of mycorrhizal associations. Biol Rev Camb Philos Soc 79(3): 473-495.

3. Smith SE, Read DJ (2008) Mycorrhizal symbiosis. ( $3^{\text {rd }}$ edn), Academic Press, New York, USA.

4. Fitter AH (2005) Darkness visible, reflections on underground ecology. Journal of Ecology 93: 231-243.

5. Santos González JC, Finlay RD, Tehler A (2007) Seasonal dynamics of Arbuscular Mycorrhizal root colonization in a semi-natural grassland. Applied and Environmental Microbiology 73(17): 5613-5623.

6. Marschner H, Dell B (1994) Nutrient uptake in mycorrhizal symbiosis. Plant and Soil 159(1): 89-102.

7. Johnson NC, Wilson GWT, Bowker MA, Wilson JA, Miller RA (2010) Resource limitation is a driver of local adaptation in mycorrhizal symbioses. PNAS 107(5): 2093-2098.

8. Soka GE, Ritchie ME (2016) Contributions of IS fungi and soil organic matter to plant productivity in tropical savanna soils under different land uses. Rhizosphere 1(1): 45-52.

9. Borowicz V (2001) Do arbuscular mycorrhizal fungi alter plant-pathogen relations? Ecology 82: 3057-3068.

10. Zhu YG, Miller RM (2003) Carbon cycling by arbuscular mycorrhizal fungi in soil-plant systems. Trends in Plant Sci 8(9): 407-409.

11. Smith FA, Grace EJ, Smith SE (2009) More than a carbon economy: Nutrient trade and ecological sustainability in facultative arbuscular mycorrhizal symbioses. New Phytol 182(2): 347-358.

12. Corrêa A, Hampp R, Magel E, Martins Loução M (2011) Carbon allocation in ectomycorrhizal plants at limited and optimal $\mathrm{N}$ supply: an attempt at unravelling conflicting theories. Mycorrhiza 21(1): 35-51.

13. Reinhardt D (2007) Programming good relations-development of the arbuscular mycorrhizal symbiosis. Curr Opin Plant Biol 10(1): 98-105.
14. Bonfante P, Genre A (2008) Plants and arbuscular mycorrhizal fungi: An evolutionary developmental perspective. Trends Plant Sci. 13(9): 492498.

15. Klironomos JN (2002) Feedback with soil biota contributes to plant rarity and invasiveness in communities. Nature 417 (6884): 67-70.

16. Jansa J, Mozafar A, Anken T, Ruh R, Sanders IR, et al. (2002) Diversity and structure of AMF communities as affected by tillage in a temperate soil. Mycorrhiza 12(5): 225-234.

17. Oehl F, Sieverding E, Ineichen K, Mäder P, Boller T, et al. (2003) Impact of land use intensity on the species diversity of arbuscular mycorrhizal fungi in agro-ecosystems of Central Europe. Appl Environ Microbiol 69(5): 2816-2824.

18. Jefwa JM, Mwangi LM, Odee D, Mugambi G (2004) Preliminary studies on mycorrhizal symbiosis in plant conservation forestry and farming systems in Kenya. Journal of Tropical Microbiology and Biotechnology 3(1): 48-62.

19. Rillig CM (2004) Arburscular Mycorrhizae and terrrestial ecosystem process. Ecology letters 7: 740-754.

20. McGuire KL, Henkel TW, Granzow de la Cerda I, Villa G, Edmund F, et al. (2008) Dual mycorrhizal colonization of forest-dominating tropical trees and the mycorrhizal status of non-dominant tree and liana species. Mycorrhiza 18(4): 217-222.

21. Soka GE, Ritchie ME (2014) Arbuscular mycorrhizal symbiosis and ecosystem processes: Prospects for future research in tropical soils. Open Journal of Ecology 4(1): 11-22.

22. Soka GE, Ritchie ME, Mayemba EP (2015) Influence of current land use and edaphic factors on Arbuscular Mycorrhizal (AM) hyphal abundance and soil organic matter in and near Serengeti National Park. Journal of Ecology and the Natural Environment 7(5): 158-169.

23. Houghton JT, Ding Y, Griggs DJ, Noguer M, van der Linden JP, et al. (2001) The Scientific Basis. Cambridge University Press, UK.

24. Yang W, Zheng Y, Gao C, He X, Ding Q, et al. (2013) The Arbuscular Mycorrhizal Fungal Community Response to Warming and Grazing Differs between Soil and Roots on the Qinghai-Tibetan Plateau. Plos One 8(9): e76447.

25. Hu Y, Rillig MC, Xiang D, Hao Z, Chen B (2013) Changes of AM fungal abundance along environmental gradients in the arid and semi-arid grasslands of northern China. Plos One 8(2): e57593.

26. Kizilkaya R, Dengiz O (2010) Variation of land use and land cover effects on some soil physico-chemical characteristics and soil enzyme activity. Zemdirbyste-Agriculture 97(2): 15-24.

27. Kizilkaya R, Bayrakli B (2005) Effects of N-enriched sewage sludge on soil enzyme activities. Applied Soil Ecology 30(3): 192-202.

28. Kennedy AC, Papendick RI (1995) Microbial characteristics of soil quality. Journal of Soil and Water Conservation 50: 243-248.

29. Leake J, Johnson D, Donnelly D, Muckle G, Boddy L et al. (2004) Networks of power and influence: the role of mycorrhizal mycelium in controlling plant communities and agro ecosystem functioning. Canadian Journal of Botany 82(8): 1016-1045.

30. Smithson PC, Giller KE (2002) Appropriate farm management practices for alleviating $\mathrm{N}$ and $\mathrm{P}$ deficiencies in low-nutrient soils of the tropics. Plant Soil 245: 169-180. 
(c) (i) Creative Commons Attribution 4.0

International License

For possible submission use the below is the URL

Submit Article
Your subsequent submission with Crimson Publishers will attain the below benefits

- High-level peer review and editorial services

- Freely accessible online immediately upon publication

- Authors retain the copyright to their work

- Licensing it under a Creative Commons license

- Visibility through different online platforms

- Global attainment for your research

- Article availability in different formats (Pdf, E-pub, Full Text)

- Endless customer service

- Reasonable Membership services

- Reprints availability upon request

- One step article tracking system 